Jurnal Indonesia Sosial Teknologi: p-ISSN: 2723 - 6609

e-ISSN : 2745-5254

Vol. 2, No. 7 Juli 2021

\title{
SISTEM HUBUNGAN INDUSTRIAL PEMBERDAYAAN MASYARAKAT ECENG GONDOK DESA BANYU HIRANG
}

\author{
Nurul Hikmah ${ }^{1}$, Maisharah ${ }^{2}$, Qhazisa Arty Qhalista ${ }^{3}$ \\ Program Studi Ilmu Pemerintahan,Fakultas Ilmu Sosial dan Ilmu Politik,Universitas \\ Muhammadiyah Malang \\ Email: uyyuy2601@gmail.com ${ }^{1}$, maisyaarh@gmail.com ${ }^{2}$, artyqhalista@gmail.com ${ }^{3}$
}

\begin{abstract}
Abstrak
Berkembangnya industri merupakan suatu perubahan sosial yang ada pada masyarakat, sedangkan industri adalah suatu upaya meningkatkan kesejahteraan penduduk. Selain itu industrialisasi juga tidak dapat terlepas dari usaha untuk meningkatkan mutu sumber daya manusia dan kemampuan untuk memanfaatkan sumber daya alam secara optimal. Penelitian bertujuan untuk mengetahui dan lebih mempererat sistem hubungan industrial pemberdayaan masyarakat melalui kerajinan eceng gondok di desa Banyu Hirang sistem hubungan industrial antara lain yaitu Kegiatan kerajinan tangan menjadi salah satu program kegiatan yang memiliki kontribusi yang besar bagi pemberdayaan masyarakat desa. Program kegiatan kerajinan tangan merupakan salah satu solusi untuk mengurangi pengangguran di pedesaan, meningkatkan pendapatan masyarakat, meningkatkan kualitas sumber daya manusia, serta mampu menciptakan lapangan pekerjaan baru dengan mengoptimalkan potensi yang ada di lingkungan pedesaan memanfaatkan tanaman eceng gondok yang masih melimpah. Metode penelitian ini menggunakan jenis penelitian kualitatatif deskriptif. Bogdan dan Tylor mendefinisikan penelitian kualitatif sebagai prosedur penelitian yang menghasilkan data deskriptif berupa kata-kata tertulis atau lisan dari orang-orang atau perilaku yang diamati. Hasil praktikum dapat memberikan tambahan refrensi untuk mahasiswa dalam Pola Hubungan Industrial Terhadap Produksi kerajinan tangan eceng gondok desa Banyu Hirang Kabupaten Hulu Sungai Utara
\end{abstract}

Kata Kunci: pemberdayaan masyarakat; eceng gondok; ekonomi masyarakat

\section{Abstract}

The development of industry is a social change that exists in society, while industry is an effort to improve the welfare of the population. In addition, industrialization cannot be separated from efforts to improve the quality of human resources and the ability to utilize natural resources optimally. The research aims to identify and further strengthen the industrial relations system for community empowerment through water hyacinth handicrafts in Banyu Hirang village. The handicraft activity program is one solution to reduce unemployment in rural areas, increase people's income, improve the quality of human resources, and be able to create new jobs by optimizing the potential that exists in the rural environment by utilizing the abundant water hyacinth plants. This research method uses descriptive qualitative research. Bogdan and Tylor define qualitative research as a research procedure 
that produces descriptive data in the form of written or spoken words from people or observed behavior. The results of the practicum can provide additional references for students in the pattern of industrial relations on the production of water hyacinth handicrafts in Banyu Hirang village, Hulu Sungai Utara Regency

Keywords: community empowerment; water hyacinth; community economy

\section{Pendahuluan}

Berkembangnya industri merupakan suatu perubahan sosial yang ada pada masyarakat, sedangkan industri adalah suatu upaya meningkatkan kesejahteraan penduduk.selain itu industrialisasi juga tidak dapat terlepas dari usaha untuk meningkatkan mutu sumber daya manusia dan kemampuan untuk memanfaatkan sumber daya alam secara optimal

Mendengar atau melihat kerajinan tangan dari tanaman eceng gondok tidak asing lagi bagi masyarakat indonesia, kerajinan dari tanaman eceng gondok sangatlah kuat dan kokoh memiliki kualitas yang bagus dan cara pembuatannya lumayan susah karena masih memakai teknik tangan bukan mesin, apabila membeli langsung di tempat pembuatan kerajinan pembeli bisa memilih berbagai modal kerajinan dan pembeli bisa pesan langsung sesuai keingan,selain itu kerajinan econg gondok ini juga menjadi oleh oleh khas daerah kabupaten Hulu Sungai Utara untuk harga kerajinan eceng gondok

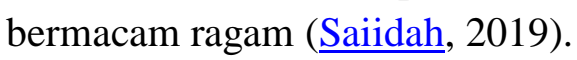

Kerajinan eceng gondok semakin banyak di butuhkan melihat banyaknya barang barang dibuat dari eceng gondok, baik untuk kebutuhan usaha, kebutuhan umum, hingga kebutuhan rumah tangga, barang dari kerajinan eceng gondok ini memiliki berbagai macam model yang unik Rendahnya sumber daya manusia di usaha atau kegiatan pengolahan bahan mentah barang setengah jadi yang memiliki nilai tambah untuk mendapatkan keuntungan, industri merupakan salah satu Indonesia berakibat pada timbulnya masalah kemiskinan dan meningkatnya penganngguran (Amalia, 2019). Permasalahan kemiskinan seringkali terkait dengan ketidakberdayaan dan kerentanan masyarakat dalam memenuhi kebutuhan hidup Kemiskinan dan pengangguran sangat identik di wilayah pedesaan (Jamaluddin, Fitriani, Safrida, \& Warjio, 2019). Masyarakat di pedesaan yang memiliki pola pikir statis, tradisional dan sulit menerima inovasi, pada akhirnya desa tidak akan mampu berkembang dan akan menjadi desa tertinggal dan terbelakang. Masalah yang ada di pedesaan perlu segera diatasi agar kualitas hidup masyarakat desa dapat meningkat. Salah satu solusinya dengan melaksanakan pembangunan masyarakat desa. Pembangunan masyarakat adalah suatu upaya terencana dan sistematis yang dilakukan oleh, untuk, dan dalam masyarakat guna meningkatkan kualitas hidup penduduk dalam semua aspek kehidupannya di dalam suatu kesatuan wilayah (Mukhlishin \& Suhendri, 2017). Pembangunan masyarakat desa akan efektif apabila melibatkan masyarakat sebagai subjek pembangunan. Dimana masyarakat terlibat secara langsung dalam proses perencanaan, pelaksanaan dan evaluasi di berbagai kegiatan pembangunan. Masyarakat diberi kuasa penuh untuk memilih. 
Kegiatan kerajinan tangan menjadi salah satu program kegiatan yang memiliki kontribusi yang besar bagi pemberdayaan masyarakat desa. Kegiatan kerajinan tangan memiliki prospek yang cerah karena produk kerajinan memiliki peran penting dalam mendukung pertumbuhan ekonomi di Indonesia (Irianto, 2020). Adanya program kegiatan kerajinan tangan merupakan salah satu solusi untuk mengurangi pengangguran di pedesaan, meningkatkan pendapatan masyarakat, meningkatkan kualitas sumber daya manusia, serta mampu menciptakan lapangan pekerjaan baru dengan mengoptimalkan potensi yang ada di lingkungan pedesaan (Sundari, 2019). Kerajinan tangan bisa dibuat dengan memanfaatkan barang-barang yang berlebihan atau bahan-bahan yang dianggap tidak berguna untuk dioah menjadi barang-barang yang multi fungsi dan bernilai ekonomis. Eceng gondok termasuk salah satu tanaman yang dapat dimanfaatkan sebagai bahan pembuatan kerajinan tangan. Tanaman eceng gondok termasuk tanaman gulma (pengganggu) karena memiliki pertumbuhan yang cepat dan dapat merusak tanaman yang ada di sekitarnya. Tanaman eceng gondok juga berdampak negatif bagi wilayah perairan seperti menimbulkan pencemaran air (Hasyim, 2016). Limbah tanaman eceng gondok yang mati akan mengalami pembusukan (dekomposisi) sehingga akan berakibat pula pada pendangkalan di wilayah perairan. Salah satu cara untuk mengurangi dampak negatif dari tanaman eceng gondok di wilayah perairan adalah dengan memanfaatkan dan mengolah tanaman eceng gondok menjadi produk kerajinan tangan (Pudjowati, Wahyuni, Afifah, Safi'i, \& Kabarudin, 2021). Kabupaten Hulu Sungai Utara terdapat salah satu desa yang bernama Desa Banyu Hirang bergerak dalam pembuatan kerajinan tangan dari eceng gondok.

Kegiatan pembuatan kerajinan tangan dari eceng gondok di Desa Banyu Hirang tersebut diberi nama 'anyaman' Kegiatan pembuatan kerajinan tangan eceng gondok 'anyaman' dilaksanakan untuk memanfaatkan tanaman eceng gondok yang masih melimpah. Selain itu dilaksanakannya kegiatan kerajinan tangan eceng gondok 'anyaman' sebagai bentuk keprihatinan pengelola 'anyaman' terhadap kondisi perekonomian di Desa Banyu Hirang yang masih rendah karena masyarakat di Desa Banyu Hirang bermata pencaharian di sektor agraris dengan menjadi petani. Pendapatan yang diperoleh dari bekerja sebagai petani tidak cukup untuk memenuhi kebutuhan hidup keluarga yang semakin bertambah Program pemberdayaan masyarakat melalui kegiatan pembuatan kerajinan tangan eceng gondok 'anyaman' di Desa Banyu Hirang dimaksudkan untuk memfasilitasi masyarakat yang memiliki keterampilan menganyam serta membantu memberdayakan masyarakat, terutama masyarakat miskin agar lebih sejahtera. Proses pelaksanaan program kegiatan pembuatan kerajinan tangan eceng gondok (Zubaedi, 2016).

Tujuan Penelitian ini adalah 1) Mengetahui pengembangan pembuatan kerajinan tangan eceng gondok 2) Mengetahui alternatif strategi yang dapat diterapkan dalam mengembangkan industri kecil pembuatan kerajinan tangan eceng gondok 3) Untuk memahami pola hubungan industrial (hubungan karyawan dengan pemilik usaha) di dalam produksi kerajinan eceng gondok 5) Untuk mengetahui bagaimana pendistribusian produksi kerajinan eceng gondok. 6) Untuk mengetahui bahan baku apa 
saja yang digunakan dalam pembuatan produksi kerajinan eceng gondok 7) Sebagai sarana untuk melatih keterampilan mahasiswa.

\section{Metode Penelitian}

Metode penelitian ini menggunakan jenis penelitian kualitatatif deskriptif. Bogdan dan Tylor mendefinisikan penelitian kualitatif sebagai prosedur penelitian yang menghasilkan data deskriptif berupa kata-kata tertulis atau lisan dari orang-orang atau perilaku yang diamati. (Lexy J Moleong, 2012) Metode kualitatif deskriptif menyesuaikan pendapat antara peneliti dengan informan. Pemilihan metode ini dilakukan karena analisisnya tidak bias dalam bentuk angka dan peniliti lebih mendeskripsikan segala fenomena yang ada dimasyarakat secara jelas. Penelitian ini dilakukan secara bertahap sesuai dengan jadwal yang telah dikemukakan diatas, yaitu untuk memperoleh data secara lengkap. Data yang telah didapat dari proses wawancara dan observasi akan di sajikan dalam bentuk deskripsi dengan menggunakan kata-kata yang mudah dimengerti. Selain itu ada juga data yang mendukung yaitu foto-foto produk yang sedang banyak di minati oleh masyarakat.

\section{Lokasi Praktikum}

Praktikum ini mengambil lokasi di Desa Banyu Hirang.Pemilihan tempat ini karena merupakan pusat industri yang cukup besar dan perlu adanya diketahui oleh masyarakat luas mengenai sentra industrinya.

\section{Teknik pengumpulan data}

Menurut (Lexi J Moleong, 2010) dalam penelitian kualitatif, pengumpulan data dilakukan pada natural setting (kondisi yang alamiah), sumber data primer, dan teknik pengumpulan data lebih banyak pada observasi, wawancara dan dokumentasi. Begitu pula data-data dalam penelitian ini berupa informasi-informasi yang didapat dari subjek penelitian dengan menggunakan teknik pengumpulan data berupa observasi, wawancara, dan dokumentasi.

\section{Analisis data}

Hasil praktikum selain akan dianalisis secara deskriptip Kualitatif penulis juga menggunakan analisis SWOT. Analisis SWOT adalah identifikasi berbagai faktor secara sistematis untuk merumuskan strategi perusahaan. Analisis ini didasarkan pada logika yang dapat memaksimalkan strengts (kekuatan) dan opportunity (peluang), namun secara bersamaan dapat memaksimalkan weaknes (kelemahan) dan treath (ancaman). Strengts (kekuatan), weaknes (kelemahan), opportunity (peluang) dan treath (ancaman) merupakan faktor-faktor strategis perusahaan yang perlu dianalisis dalam kondisi yang ada saat ini. Hal ini disebut pula analisis situasi dengan model analisis SWOT. 


\section{Validitas data}

Dalam hal ini ada teknik yang digunakan yakni, trigulasi sebagai cara membandingkan hasil wawancara, membandingkan keadaan perspektif seseorang dengan berbagai pendapat orang lain dan membandingkan hasil wawancara dengan isi dokumen yang berkaitan. Kemdian pengamatan dilakukan adalah dengan teliti dan rinci serta berkesinambungan terhadap masyarakat dan distributor yang berada diwilayah Desa Banyu Hirang.

\section{Hasil dan Pembahasan}

Pembahasan Kegiatan kerajinan tangan eceng gondok merupakan salah satu bentuk kegiatan pemberdayaan masyarakat karena proses pelaksanaan kegiatan produksi kerajinan tangan eceng gondok dilaksanakan secara bertahap dan berkesinambungan.

\section{a. Proses pemberdayaan masyarakat.}

Faktor penghambat Faktor penghambat dalam proses pembuatan kerajinan tangan eceng gondok yaitu sebagai berikut: kurangnya tenaga kerja, perubahan cuaca yang tidak menentu mengakibatkan eceng cepat menjamur jika tidak kering merata (Murdani \& Hadromi, 2019).

\section{b. Dampak pemberdayaan masyarakat}

1. Segi ekonomi, pendapatan tenaga kerja semakin meningkat.

2. Segi sosial, membuka lapangan pekerjaan, memberikan kesempatan kerja bagi masyarakat yang membutuhkan pekerjaan dan mengurangi pengangguran di daerah pedesaan. Selain itu semakin mempererat tali persaudaraan antarsesama manusia.

3. Segi lingkungan, membantu pemerintah dalam mengurangi dampak negatif dari adanya tanaman eceng gondok di perairan Indonesia (Winata \& Muchid, 2018).

\section{c. Faktor pendukung}

1) Bahan baku eceng gondok yang mudah di dapat dan murah. Tanaman eceng gondok mampu hidup di daerah iklim tropis sampai subtropis. Sehingga Indonesia sebagai salah satu negara beriklim tropis tidak sulit untuk menemukan tanaman eceng gondok, baik di sungai, rawa, maupun danau.

2) Mudahnya pemasaran produk kerajinan eceng gondok. Pemasaran produk yang mudah karena masih banyaknya peminat terhadap produk dari bahan alami seperti eceng gondok khususnya dari pangsa luar negeri.

\section{d. Dampak}

1. Segi ekonomi Penghasilan dan pendapatan tenaga kerja semakin meningkat, dapat memenuhi kebutuhan primer maupun sekunder, dan mampu meningkatkan status ekonomi masyarakat di pedesaan.

2. Segi sosial, membuka lapangan pekerjaan, memberikan kesempatan kerja bagi masyarakat yang membutuhkan pekerjaan dan mampu mengurangi 
pengangguran di daerah pedesaan. Selain itu semakin mempererat tali persaudaraan antarsesama manusia.

3. Segi lingkungan, membantu pemerintah dalam mengurangi dampak negatif dari adanya tanaman eceng gondok di perairan Indonesia.

4. Segi pendidikan, pengetahuan, sikap dan keterampilan masyarakat meningkat dan bertambah mengenai bidang kerajinan khususnya kerajinan tangan dari eceng gondok.

\section{Kesimpulan}

Kesimpulan ini adalah 1) Proses pemberdayaan masyarakat melalui kegiatan kerajinan tangan eceng gondok terjadi melalui empat tahapan yaitu: a) tahap penyadaran, b) tahap penguatan potensi atau daya, c) tahap pelaksanaan tindakan nyata, dan d) tahap evaluasi. 2) Faktor pendukung dan penghambat dalam pemberdayaan masyarakat melalui kegiatan kerajinan tangan eceng gondok a. Faktor pendukung yaitu (a) bahan baku eceng gondok mudah di dapat dan murah, (b) mudahnya pemasaran poduk, (c) proses pembuatan kerajinan eceng gondok mudah, (d) tersedianya sarana dan prasarana yang memadai, (e) adanya motivasi dan minat yang tinggi dari tenaga kerja, (f) adanya. 3) Dampak dari adanya pemberdayaan masyarakat melalui kegiatan kerajinan tangan eceng gondok 
Sistem Hubungan Industrial Pemberdayaan Masyarakat Eceng Gondok Desa Banyu

Hirang

\section{Bibliography}

AMALIA, ENIK. (2019). Pemberdayaan Masyarakat Melalui Produksi Kerajinan Eceng Gondok Dalam Meningkatkan Pendapatan Keluarga Di UKM Karang Pilang Bersatu Surabaya. J+ PLUS UNESA, 8(1).

Hasyim, Nur Azizah. (2016). Potensi Fitoremediasi Eceng Gondok (Eichornia Crassipes) Dalam Mereduksi Logam Berat Seng (Zn) Dari Perairan Danau Tempe Kabupaten Wajo. Universitas Islam Negeri Alauddin Makassar.

Irianto, Jusuf. (2020). Memetik Hikmah Sebuah Wabah. Airlangga University Press.

Jamaluddin, Yanhar, Fitriani, Fitriani, Safrida, Safrida, \& Warjio, Warjio. (2019). Strategi dan Model Pemberdayaan Masyarakat Miskin di Sumatera Utara. Jurnal Administrasi Publik: Public Administration Journal, 9(1), 21-30.

Moleong, Lexi J. (2010). Methodology of Qualitative Research. Bandung: Remaja Rosda Karya.

Moleong, Lexy J. (2012). Metodologi Penelitian Kualitatif, Bandung. Pariwisata Pedesaan Sebagai Alternatif Pembangunan Berkelanjutan (Laporan Penelitian Hibah Bersaing Perguruan Tinggi) Yogyakarta.

Mukhlishin, Ahmad, \& Suhendri, Aan. (2017). Aplikasi Teori Sosiologi dalam Pengembangan Masyarakat Islam. INJECT (Interdisciplinary Journal of Communication), 2(2), 211-234.

Murdani, Murdani, \& Hadromi, Hadromi. (2019). Pengembangan Ekonomi Masyarakat Melalui Pemberdayaan Usaha Mikro Kecil dan Menengah (Studi di Kelurahan Kandri Kecamatan Gunungpati Kota Semarang). Jurnal Abdimas, 23(2), 152-157.

Pudjowati, Juliani, Wahyuni, Susi Tri, Afifah, Novelita Nur, Safi'i, Brillian Ayu Cahyaning, \& Kabarudin, Kharisma Masithah. (2021). Pemanfaatan Tanaman Enceng Gondok Sebagai Peluang Usaha Kerajinan Anyaman Di Kelurahan Kebraon Karangpilang Surabaya. Jurnal Pengabdian Masyarakat Indonesia, 1(2), $65-70$.

Saiidah, Fitriana Fatchatus. (2019). Pemberdayaan masyarakat melalui pemanfaatan enceng gondok danau Rawa Pening oleh Kelompok Usaha Pemuda Produktif (KUPP) Karya Muda Syarina Production: studi di Desa Kebondowo Kecamatan Banyubiru Kabupaten Semarang. UIN Walisongo.

SUNDARI, PIPIT. (2019). Peran Serikat Pekerja dalam Mengoptimalkan Kualitas Hubungan Industrial: studi Kasus Dikabupaten Semarang. Jurnal REKOMEN (Riset Ekonomi Manajemen), 2(2).

Winata, Septiani Putri, \& Muchid, Muchid. (2018). Peran Lembaga Pemberdayaan Masyarakat Kelurahan dalam Memberdayakan Masyarakat di Kelurahan Sungai 
Nurul Hikmah, Maisharah, Qhazisa Arty Qhalista

Pagar Kecamatan Kampar Kiri Kabupaten Kampar Tahun 2016. Riau University.

Zubaedi, M. Ag. (2016). Pengembangan masyarakat: wacana dan praktik. Kencana. 